\section{Do Clinical Experience Time and Postgraduate Training Influence the Choice of Materials for Posterior Restorations? Results of a Survey with Brazilian General Dentists}

Gustavo Giacomelli Nascimento ${ }^{1}$, Marcos Britto Correa ${ }^{1}$, Niek Opdam², Flávio Fernando Demarco ${ }^{1,3}$
'Graduate Program in Dentistry, School of Dentistry, UFPel - Federal University of Pelotas, Pelotas, RS, Brazil

${ }^{2}$ Department of Preventive and Restorative Dentistry, Radboud University, Nijmegen Medical Centre, Nijmegen, The Netherlands ${ }^{3}$ Graduate Program in Epidemiology, School of Dentistry, UFPel - Federal University of Pelotas, RS, Brazil

Correspondence: Prof. Dr. Flávio Fernando Demarco, Rua Gonçalves Chaves, 457, 50 andar, Centro, 96015560 Pelotas, RS, Brasil. Tel: +55-533225-6741. e-mail: flavio.demarco@ pq.cnpq.br; ffdemarco@gmail.com

Key Words: composite resins, cross-sectional studies, dentists, dental restoration, permanent.

\section{Introduction}

Even with the decrease in caries prevalence, there is still a great demand for restorative dental treatment, especially in posterior teeth and among specific population risk groups (1). Direct restorations are still the first choice to treat posterior carious teeth, due to the low cost compared to indirect restorations and comparable longevity (2), the small loss of sound tooth structure that needs to be removed and, when applied, the adhesive technology enables minimal invasive preparations (3). In the past, dental amalgam was the most used material for posterior restorations, combining simple handling, low cost and good longevity (4). Nevertheless, owing to esthetic demands of patients and the fact that minimally invasive treatment options are related to adhesive restorations $(2,5)$, its use is in demise around the world. It is important to highlight that this change from amalgam to adhesive techniques using composite resin is not taking place identically all over the world. In some countries, like the US, dental schools are still teaching several contra-indications for using posterior composite (6), thus amalgam is still considered as the first choice material (7), whereas in other countries, like Western Europe, extensive training on composite placement is included (8), and the teaching of amalgam has been omitted from dental curricula (9).

Different types of composite resins have been launched to the market to offer the dentists better mechanical properties, such as a more polishable surface (microfilled resin) or a combination of resistance and surface smoothness (microhybrid resin). Recently, nanofillers have been incorporated in resin composites, claiming to provide improved mechanical properties, combining polishability and strength (5).

Due to the great number of restorative materials available for posterior teeth, some studies have investigated which factors would be associated with dentist's selection of materials, demonstrating that variables related to the tooth, to the patient and to the dentist could influence on this decision $(1,4)$. However, most of these studies were conducted before or around year 2000, when amalgam was still considered the first choice for posterior teeth $(4,10)$. Also, time since graduation and attendance to continuous education courses (post-graduation training) may influence the materials' selection $(1,11)$. The working place may also influence material selection, with those working in the public service showing a trend for more amalgam 
placements (1). Moreover, different dentist/inhabitant ratios and different health care regulations (public, insurance or out-of-pocket) may play an important role when a dentist has to make choices.

The aim of this study was to assess whether the clinical experience time (time since graduation), level of specialization (post-graduation training), and working place influence dentists' choices of the material for posterior restorations.

\section{Material and Methods}

This cross-sectional study was performed between March and June 2009 in Pelotas, a medium-sized city in the southern region of Brazil. All dentists registered $(n=276)$ at the Regional Council of Dentistry (CRO, in Portuguese)/Pelotas Division were invited to participate in the study. Data were collected through a self-applied questionnaire with closed questions. The variables comprised sociodemographic information (gender and skin color), professional characteristics (graduation time, level of specialization and working place), and information regarding first choice of material for posterior restorations (amalgam, direct composite, indirect restoration) and the type of composite resin used for posterior restorations (microhybrid, microfilled, nanohybrid, condensable, flow) and use of rubber dam (yes/no). The questionnaire did not collect any information that could allow identification of any participant, and was pre-tested with professionals not involved in the study. The Ethics Committee of the Federal University of Pelotas approved the research protocol under registration number 116/2009. Further information about this methodology is published elsewhere $(11,12)$.

The questionnaires were personally delivered to each dentist's office and an explanation was given to dentists about the importance of their participation and the study purposes. The questionnaires were collected 1 week later together with the signed informed consent form. Loss of participants was considered when professionals did not return the questionnaire after two visits.

Data were submitted to descriptive analyses and the association existing between vital time since graduation and post-graduation training was tested with chi-square or Fisher's exact test. The analyses were carried out with Stata 10.0 software (StataCorp, College Station, TX, USA). A significance level of $\alpha=0.05$ was adopted for the study.

\section{Results}

From the total of 276 dentists registered at the CRO-Pelotas Division, who were visited and received the questionnaire, 187 participated in the study, resulting in a response rate of $68 \%$. The losses were mainly related to lack of returning the questionnaire or signing the informed consent, but there were some refusals as well. As the questionnaire was self-applied, some of the dentists missed some questions and the number of answers varied for each question.

Descriptive analysis (Table 1) showed that $52.4 \%$ of the dentists were females and in relation to skin color, 96\% of the participants classified themselves as White. A time since graduation $\geq 10$ years $(45.4 \%)$ was the most frequent and $64.7 \%$ of the dentists had been trained in some kind of formal continuing education (i.e., master's degree, $\mathrm{PhD}$ degree, specialization course). In relation to the working place, $66.1 \%$ spent more time in private practice.

Direct composite resin was selected by $73.2 \%$ as the first-choice material for restoration of posterior teeth, while amalgam was preferred by $19.0 \%$ of the dentists, followed by indirect composite resins (7.9\%). Regarding the type of direct composite, microhybrid resins were selected by $74.5 \%$ of the dentists, and microfilled resins were preferred by $10.5 \%$ of the professionals. Fifty-seven percent of the dentists did not use rubber dam isolation in daily practice for placement of posterior restorations.

The results showed a significant association of years of professional experience with the type of material selected. It was observed that preference for amalgam was more common among dentists with a longer time since graduation ( $p=0.014)$ (Table 2). The working environment did not present a significant difference with material choice, although a borderline relation was found between dentists who work in public service and the use of amalgam for

Table 1. Number of observations and frequencies of the studied variables among dentists. Pelotas, RS, Brazil $(n=187)$

\begin{tabular}{lcc}
\hline Variable & $\mathrm{n}^{*}$ & $\%(\mathrm{Cl} 95 \%)$ \\
\hline Type of material & 164 & \\
Amalgam & 31 & $18.9(13.2-25.7)$ \\
Direct composite resin & 120 & $73.2(65.7-79.8)$ \\
Indirect restoration & 13 & $7.9(4.2-13.2)$ \\
Type of composite & 153 & \\
Microhybrid & 114 & $74.5(66.8-81.2)$ \\
Microfilled & 16 & $10.5(6.3-16.4)$ \\
Nanohybrid & 11 & $7.2(3.9-12.6)$ \\
Flow & 10 & $6.5(3.0-11.1)$ \\
Condensable & 02 & $1.3(0.1-0.5)$ \\
Rubber dam usage & 169 & \\
No & 97 & $57.4(49.6-64-9)$ \\
Yes & 72 & $42.6(35.4-50.4)$ \\
\hline
\end{tabular}

* Number of valid observations. 
posterior restorations $(\mathrm{p}=0.068)$, indicating that amalgam is more often chosen in the public service.

Table 3 summarizes the association of restorative procedures and the level of specialization of dentists.

Table 2. Association between the time of clinical practice (time since graduation) of dentists and variables related to practices for posterior restorations. Pelotas, RS, Brazil ( $n=187)$.

\begin{tabular}{|c|c|c|c|c|c|}
\hline \multirow{2}{*}{ Variable } & \multicolumn{5}{|c|}{ Time since graduation in years $[\mathrm{n}(\%)]$} \\
\hline & $\leq 10$ & $11-20$ & $>21$ & Total & $p$ value \\
\hline Type of material & & & & & 0.014 \\
\hline Amalgam & $9(29.0)$ & $7(22.6)$ & $15(48.4)$ & 31 & \\
\hline Direct composite resin & $68(57.6)$ & $23(19.5)$ & 27 (22.9) & 118 & \\
\hline Indirect restoration & $4(30.8)$ & $4(30.8)$ & $5(38.5)$ & 13 & \\
\hline Type of composite & & & & & 0.071 \\
\hline Microhybrid & $63(56.2)$ & $24(21.4)$ & $25(22.3)$ & 112 & \\
\hline Microfilled & $7(43.7)$ & $3(18.8)$ & $6(37.5)$ & 16 & \\
\hline Nanohybrid & $3(27.3)$ & $1(9.1)$ & $7(63.3)$ & 11 & \\
\hline Condensable & $4(40.0)$ & $3(30.0)$ & $3(30.0)$ & 10 & \\
\hline Flow & 0 & 0 & $2(100.0)$ & 2 & \\
\hline Rubber dam use & & & & & 0.270 \\
\hline No & $50(52.1)$ & 17 (17.7) & $29(30.2)$ & 96 & \\
\hline Yes & 31 (43.7) & $20(28.2)$ & $20(28.2)$ & 71 & \\
\hline
\end{tabular}

Table 3. Association between the post-graduation training of dentists and variables related to practices for posterior restorations. Pelotas, RS, Brazil ( $n=187)$.

\begin{tabular}{lcccc}
\hline \multirow{2}{*}{ Variable } & \multicolumn{4}{c}{ Post-graduation training [n (\%)] } \\
\cline { 2 - 5 } Type of material & No & Yes & Total & $p$ value \\
\cline { 2 - 6 } Amalgam & $12(38.7)$ & $19(61.3)$ & 31 & \\
Direct composite resin & $47(40.5)$ & $69(59.5)$ & 116 & \\
Indirect restoration & $4(33.3)$ & $8(66.7)$ & 12 & \\
Type of composite & & & & 0.071 \\
Microhybrid & $42(37.8)$ & $69(62.2)$ & 111 & \\
Microfilled & $6(37.5)$ & $19(67.5)$ & 16 & \\
Nanohybrid & $4(36.4)$ & $7(63.6)$ & 11 & \\
Condensable & $5(55.6)$ & $4(44.4)$ & 9 & \\
Flow & 0 & $2(100.0)$ & 2 & \\
Rubber dam use & & & & \\
No & $46(48.9)$ & $48(51.1)$ & 94 & \\
Yes & $19(27.1)$ & $51(72.9)$ & 70 & \\
\hline
\end{tabular}

Although most participants did not use rubber dam, the use of rubber dam was significantly higher among specialists (72.9\%) compared with non-specialists (27.1\%).

\section{Discussion}

To the best of our knowledge, this is the first survey among Brazilian dentists assessing the first-choice material for posterior restorations and factors that may influence this choice. Even though it is a cross-sectional study, it could be representative for the studied population, as all dentists registered at the CRO-Pelotas Division were contacted. Although Pelotas is a mediumsized city located in Southern Brazil, data may be representative for most regions of Brazil, once a very high dentist ratio/people $(1: 800)$ and an identical health care system are observed.

Most dentists preferred direct composite resin for posterior restorations, followed by amalgam and indirect restorations. Direct composite has been chosen as a first option for posterior teeth, as previously described in many similar studies. In a recent study conducted in Norway, dentists also preferred direct composite for Class II preparations, followed by amalgam and glass ionomer cement. However, amalgam was preferred in more challenging restorations with respect to caries activity, lesion depth, and tooth type (10). Correa et al. (1) demonstrated amalgam restorations were more commonly observed in individuals who accessed dental services by private insurance or public free at ages 15 and 24 and in those presenting a greater DMFT index at age 24. Those authors also observed that the frequency of amalgams decreased with increasing number of surfaces involved in the cavity preparation and was almost 5 times greater in molars than in premolars. The number of amalgam restorations substantially decreased in relation to composites, from older to newer restorations. This development can also be observed in other countries, but with at a different rate. Indirect restoration was the last treatment option for posterior restorations, probably because it is time-consuming, requiring at least two visits, it is a technique-sensitive procedure with additional clinical steps, and is more expensive than direct restorations (13).

In relation to type of composite, microhybrid resin was preferred by most dentists, followed by microfilled and nanohybrid composites. Microhybrid composites are considered universal materials and may be used in both anterior and posterior teeth, thus combining the mechanical properties of hybrid composites and the polishing characteristics of microfilled composites $(5,13,14)$. These factors, associated with an adequate clinical performance in 
the long term, may explain a widespread use of microhybrid composites in the studied population even for anterior teeth (11). The main reason for developing microfilled composites was to improve the esthetics of composite restorations by producing a smoother surface, similar to enamel (15). However, these materials have limitations for applications in stress-bearing areas and they are restricted to anterior teeth or Class V restorations in posterior teeth (2). In spite of this, almost 10\% of the interviewed dentists chose this material for posterior restorations, showing that some professionals are using an unsuitable material for this type of restoration. Nanofilled composites are a relatively new class of composite material (16), but the claimed improved material properties such as better polishability and strength were not demonstrated in long-term clinical studies (2). Among the dentists in this survey, the use of nanofilled composites was limited, possibly because of the higher cost of these composites. Evaluating the use of different composite for anterior teeth in the same sample size, Demarco et al. (11) observed that dentists selected most frequently microhybrid composites together with simplified adhesives and LED (light emitting diodes) curing units. There is strong evidence in literature showing that microhybrid composites have an acceptable performance for anterior and posterior teeth (3), even in long time follow-ups $(13,14)$. However, it is important to highlight that variables such as patient's risk of caries (17) or socioeconomic level (18) may play a more important role than the material's properties.

In the present study, more than half of dentists did not isolate the operative field with a rubber dam to place posterior composite restorations, which is in accordance with questionnaire-based studies conducted in different countries $(19,20)$. In an American survey that recorded if restorative procedures were done under rubber dam isolation, 63\% of dentists in a practice-based research group reported that never used a rubber dam, although its use is often recommended and, in several dental schools, it is still taught that placement of a posterior composite without a rubber dam is contra-indicated (6). There is no clinical evidence that better restorations are obtained when rubber dam is used. Studies comparing longevity showed similar results when composite restorations were placed with or without rubber dam application (21), with good results in long time clinical performance for restorations placed without rubber dam $(22,23)$. In the conducted study, professionals with some kind of post-graduation training used rubber dam more frequently than those who did not attend continued education courses. Lynch and McConnell (18) suggested that specialists are more likely to be exposed to rubber dam placement during the course of specialization. Moreover, specialists tend to do more complex procedures, which require a more qualified sensitive technique (21). In a similar manner, dentists with post-graduation training chose more frequently rubber dam to perform anterior composite restorations (11).

Time since graduation had a significant influence relative to the type of material selected for restoring posterior teeth. Dentists who graduated earlier (more than 20 years ago) used fewer composite restorations than dentists who finished the dental school more recently (less than 10 years). It is a widespread shift that the teaching of amalgam restorations to undergraduate students is in demise or even discontinued at some dental schools (9). Meanwhile, composite teaching has increased in many countries in the last decade, and consequently students have placed more posterior composite than amalgam throughout dental school (24), which reflects on the findings of the present study. Regarding the use of composite, it was also suggested that Brazilian dentists tend to rely on adhesive materials in cases where large amounts of dental structure need be removed in order to improve the resistance of the restored tooth (1).

A limitation of the present study is related to the use of questionnaires in a cross-sectional survey. However, a questionnaire can be very useful to evaluate how dentists are working in their offices and to assess how updated they are in relation to recent advances in material development and techniques $(19,20)$. The response rate obtained was $68 \%$, and losses and refusals were reduced because dental offices were visited at least twice in the attempts to recover the questionnaires. This response rate is acceptable, since rates around 50\% have been reported in similar surveys $(19,25)$. Therefore, when there is a good level of agreement on certain questions, these responses may be extrapolated to a population of dentists in Southern Brazil, as previously reported for Dentists in UK (25).

The present findings demonstrated that direct composite was the first choice material for posterior restorations among the surveyed dentists, microhybrid was the preferred type of composite and the use of rubber dam for composite resin placement in posterior teeth was not frequent. In addition, time since graduation and level of specialization affected the dentists' choices. Use of composite for posterior restorations has increased worldwide, due to better properties of these materials. Hence, dental schools should adapt their curriculum and provide specific training in order to produce restorations that last longer, mainly considering that operator and patient variables may have a stronger influence on longevity than the used material $(2,17,18)$.

The results of this survey revealed that direct composite was the first choice of dentists for posterior restorations; microhybrid was the preferred type of composite and the use of rubber dam for composite resin placement in 
posterior teeth was not frequent; time since graduation and level of specialization affected dentists' choices.

\section{Resumo}

0 objetivo deste estudo foi avaliar as possíveis opções restauradoras para dentes posteriores. Além disso, foi avaliada a possivel relação entre tempo de formação e grau de formação profissional com suas escolhas. Este estudo transversal foi realizado a partir de questionários respondidos por cirurgiões-dentistas da cidade de Pelotas/RS. Foram avaliadas variáveis sociodemográficas, nivel de especialização e ano de graduação. Além disso, foram obtidas informações sobre a primeira opção restauradora para dentes posteriores, tipo de resina composta e uso de isolamento absoluto. Dados foram submetidos à análise descritiva, e as associações foram testadas por meio do teste de Chi-quadrado ou do teste exato de Fisher, quando apropriado. A taxa de resposta foi de $68 \%$. Os cirurgiões-dentistas, em sua maioria, escolheram o uso de resina composta como a primeira opção restauradora para dentes posteriores. Em relação ao tipo de resina usada, a maioria dos profissionais escolheu a resina microhibrida; e apenas $42.6 \%$ utilizou isolamento absoluto para a realização da restauração posterior. Cirurgiões-dentistas com mais tempo de graduação utilizaram menos resina composta para dentes posteriores $(p=0.014)$. Cirurgiões-dentistas que frequentaram cursos de pós-graduação usaram mais isolamento absoluto $(p=0.006)$. Restauração direta de resina composta foi a primeira opção de tratamento restaurador para dentes posteriores; resina composta microhibrida foi o tipo de resina preferido pelos cirurgiões-dentistas e o uso de isolamento absoluto para realização de restaurações posteriores não foi frequente. Tempo desde a graduação e grau de especialização influenciaram a escolha dos cirurgiões-dentistas.

\section{References}

1. Correa $M B$, Peres $M A$, Peres $K G$, Horta $B L$, Barros $A D$, Demarco FF. Amalgam or composite resin? Factors influencing the choice of restorative material. J Dent 2012;40:703-710.

2. Demarco FF, Corrêa MB, Cenci MS, Moraes RR, Opdam NJ. Longevity of posterior composite restorations: not only a matter of materials. Dent Mater 2012;28:87-101.

3. Moura FR, Romano AR, Lund RG, Piva E, Rodrigues Júnior $S A$, Demarco FF. Three-year clinical performance of composite restorations placed by undergraduate dental students. Braz Dent J 2011;22:111-116.

4. Lubisich EB, Hilton TJ, Ferracane JL, Pashova HI, Burton B. Association between caries location and restorative material treatment provided. J Dent 2011;39:302-308.

5. Ferracane JL. Resin composite - state of the art. Dent Mater 2011;27:29-38.

6. Lynch $C D$, McConnell RJ, Wilson NH. Teaching the placement of posterior resin-based composite restorations in U.S. dental schools. J Am Dent Assoc 2006;137:619-625.

7. Kovarik RE. Restoration of posterior teeth in clinical practice: evidence base for choosing amalgam versus composite. Dent Clin North Am 2009;53:71-76

8. Wilson NH, Mjor IA. The teaching of Class I and Class II direct composite restorations in European dental schools. J Dent 2000;28:15-21.
9. Roeters FJ, Opdam NJ, Loomans BA. The amalgam-free dental school. J Dent 2004;32:371-377.

10. Vidnes-Kopperud S, Tveit AB, Gaarden T, Sandvik L, Espelid I. Factors influencing dentists' choice of amalgam and tooth-colored restorative materials for Class II preparations in younger patients. Acta Odontol Scand 2009;67:74-79.

11. Demarco FF, Baldissera RA, Madruga FC, Simoes RC, Lund RG, Correa $M B$, et al.. Anterior composite restorations in clinical practice: findings from a survey with general dental practitioners. J Appl Oral Sci 2013 [Epub ahead of print. DOI: 10.1590/1679-775720130013]

12. Demarco FF, Conde MC, Ely C, Torre EN, Costa JRS, Fernandez MR, et al.. Preferences on vital and nonvital tooth bleaching: a survey among dentists from a city of Southern Brazil. Braz Dent J 2013:24:527-531.

13. Da Rosa RPA, Donassollo TA, Cenci MS, Loguércio AD, Moraes RR, Bronkhorst EM, et al.. 22-Year clinical evaluation of the performance of two posterior composites with different filler characteristics. Dent Mater 2011;27:955-963.

14. Baldissera RA, Corrêa MB, Schuch $H$, Collares $K$, Nascimento GG, Jardim PS, et al.. Are there universal restorative composites for anterior and posterior teeth? J Dent 2013;41:1027-1035.

15. Lopes MB, Saquy PC, Moura SK, Wang L, Graciano FM, Correr Sobrinho $L$, et al.. Effect of different surface penetrating sealants on the roughness of a nanofiller composite resin. Braz Dent J 2012;23:692697.

16. Rodrigues Junior SA, Zanchi CH, Carvalho RV, Demarco FF. Flexural strength and modulus of elasticity of different types of resin-based composites. Braz Oral Res 2007;21:16-21.

17. Correa MB, Peres MA, Peres KG, Horta BL, Barros AD, Demarco FF. Do socioeconomic determinants affect the quality of posterior dental restorations? A multilevel approach. J Dent 2013;41:960-967.

18. van de Sande FH, Opdam NJ, Rodolpho PA, Correa MB, Demarco FF, Cenci MS. Patient risk factors' influence on survival of posterior composites. J Dent Res 2013;92:78S-83S.

19. Lynch CD, McConnell RJ. Attitudes and use of rubber dam by Irish general dental practitioners. Int Endod J 2007;40:427-432.

20. Gilbert GH, Litaker MS, Pihlstrom DJ, Amundson CW, Gordan W. Rubber dam use during routine operative dentistry procedures: findings from the Dental PBRN. Oper Dent 2010;35:491-499.

21. Brunthaler A, Konig F, Lucas T, Sperr W, Schedle A. Longevity of direct resin composite restorations in posterior teeth. Clin Oral Investig 2003;7:63-70

22. Opdam NJ, Bronkhorst EM, Loomans BA, Huysmans MC. 12-year survival of composite vs. amalgam restorations. J Dent Res 2010;89:1063-1067.

23. Pallesen U, Qvist V. Composite resin fillings and inlays. An 11-year evaluation. Clin Oral Investig 2003;7:71-79.

24. Lynch CD, Frazier KB, McConnell RJ, Blum IR, Wilson NH. Minimally invasive management of dental caries: contemporary teaching of posterior resin-based composite placement in U.S. and Canadian dental schools. J Am Dent Assoc 2011;142:612-620.

25. Gilmour AS, Latif $M$, Addy LD, Lynch $C D$. Placement of posterior composite restorations in United Kingdom dental practices: techniques, problems, and attitudes. Int Dent J 2009;59:148-154.

Received September 22, 2013 Accepted November 22, 2013 